\title{
Dr. Science Goes to Washington: A Transition from Research to Science and Technology Policy
}

\author{
Kelly Kirkpatrick
}

It is not uncommon to watch people's eyes shift uneasily and eventually glaze over when I talk about my doctoral research in materials science and engineering. Such public reactions are a challenge for me, not an insult to my scientific pursuits. While I rarely talk explicitly about my dissertation work to nonscientists, I have dedicated my current professional endeavors to bridging the communication gap between scientists and policymakers by filling the role of someone who can understand the language of both. I work in Washington, DC with policymakers and politicians on policy issues related to science and technology (S\&T).

One could argue: Give it up, why bother trying to explain the science and technology to the general public or to politicians and policymakers?

Plain and simple, I think it is important for nonscientists, especially those who develop policies to support federally funded research and development (R\&D), to understand the importance of investments in R\&D. Of equal importance, I have chosen to play a role in helping the scientific community, the materials science and engineering community in this case, to gain an understanding of and to develop skills on how to provide these "federal bankers" the tools to create federal initiatives and programs.

While I have always been interested in science, my interest in combining science with economic policy did not begin until I was a graduate student at Northwestern University in Chicago. I had an opportunity to work as a graduate fellow at the Department of Energy's Argonne National Laboratory where I was first exposed to ways technical information was transferred from laboratories to the marketplace. At the same time, my late husband was diagnosed with cancer, which caused me to consider the impact of scientific discovery on the medical world. His illness played a major role in changing my focus from a narrow scope of fundamental research for my dissertation to consideration of broader based $R \& D$ issues like technology transfer, globalization, intellectual property, scientists communicating with nonscientists, policy, and politics.

These two major life experiences prompted me to think about a different way I could use my technical background. I began to look at the way in which scientists and engineers describe

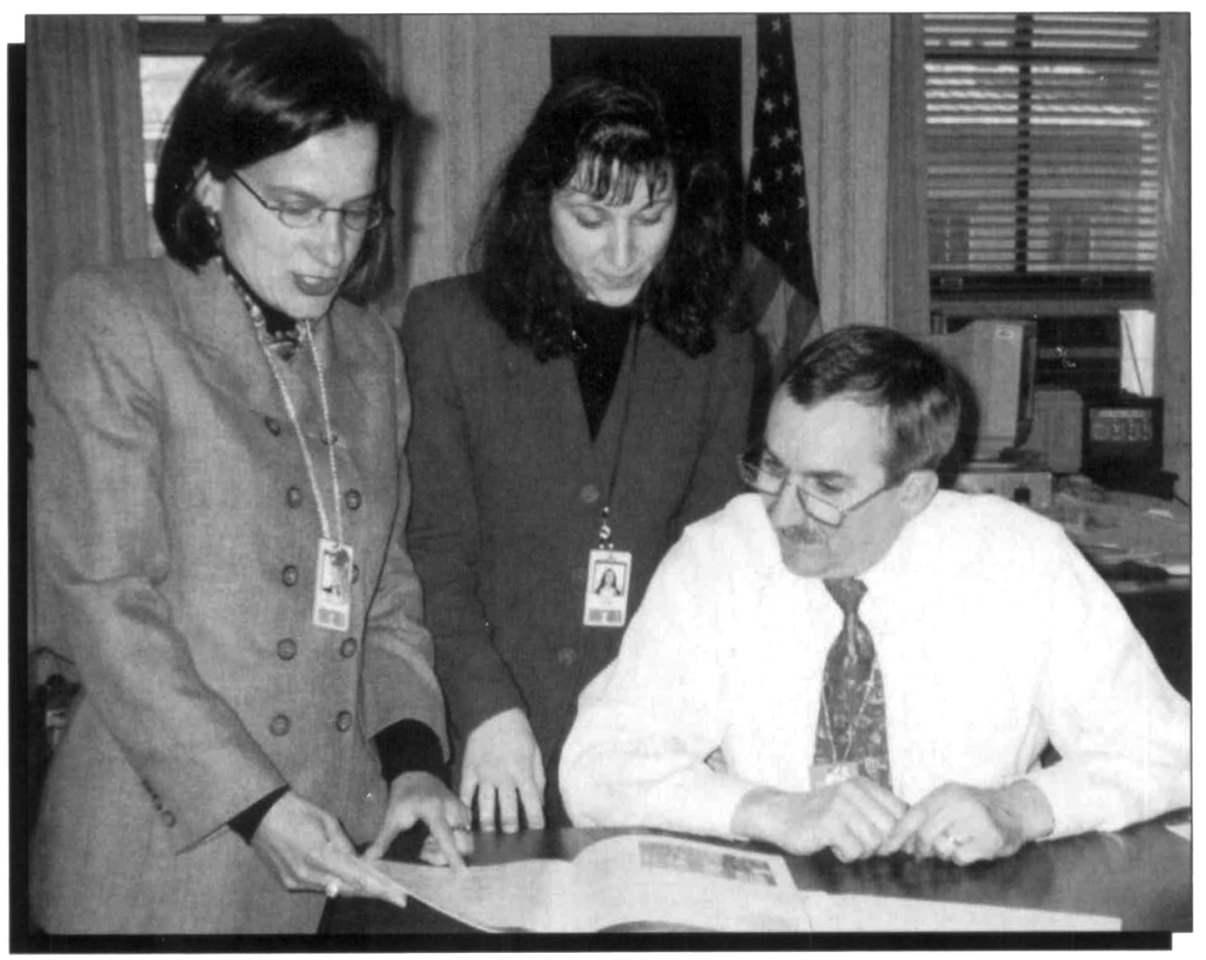

Senior policy analyst Kelly Kirkpatrick (left) is briefing Duncan Moore, Associate Director for Technology, Office of Science and Technology Policy, and Susan Ipri Brown, an American Society of Mechanical Engineers Fellow, on an idea for an Administration science and technology event.

their work to the public. I realized that unlike the medical, legal, and countless other professional communities, the materials community does not have a solid handle on how to effectively convey our interests and priorities to the key policy players in Washington.

The torch I chose to carry is one that would help bridge the two communities together on various matters of relevance to the technical world. I help bridge the communications gap between scientists, policymakers, and politicians by developing nontechnical ways to deliver technical messages so that everyone is speaking the same language. Most elected officials and staff who are responsible for the federal $R \& D$ budget do not have technical backgrounds. Most scientists and engineers who are responsible for educating the elected officials and their staff on the

Career Clips explores the range of career possibilities in, or related to, materials science. importance of investing in $R \& D$ are not well-versed in policy and legal jargon. In my experience, the most effective way to ensure a captive audience who is also eager to engage in brainstorming together on policy issues is by linking technical merits to health, education, jobs, the environment, national security, economic stability, or other societal benefits.

I began this professional journey by serving as the first Materials Research Society/Optical Society of America Congressional Fellow in 1995. I was selected to participate in a congressional fellowship program operated by the American Association for the Advancement of Science (see website http:/ / www.aaas. org/ for more information). With 34 other scientists and engineers with $\mathrm{PhD}$ degrees, I was groomed to serve on a one-year term as a science advisor for elected officials in the U.S. Senate or the U.S. House of Representatives. I had the distinct honor to work in the office of Senator Joseph Lieberman (D-Conn.) with his legislative director, Bill Bonvillian, and worked on issues ranging 
from prevention of the dismantlement of the Department of Commerce to the formation of a bipartisan Senate manufacturing task force. Discussing my ideas and experience as a congressional fellow with Ron Kelley, Congressional liaison from the MRS Office of Public Affairs, proved fruitful as I learned to think as a technical policymaker.

My next step was to leave Washington and use my skills base to work with leaders in R\&D on developing not only effective modes of communication with Washington, but also to help foster a strong network of contacts in the Capitol, As a science policy coordinator at the U.S. Department of Energy's Sandia National Laboratories in Albuquerque, New Mexico, I devoted my time helping Robert J. Eagan, Sandia's Vice President of Physical and Components Division, and his staff to articulate Sandia's research programs in clear and nontechnical terms to the Washington S\&T players. This invaluable experience also helped me gain a bird's eye view of how

\section{Resource Guide}

Books:

- A Ph.D. Is Not Enough : A Guide to Survival in Science, Peter J. Feibelman (Perseus Books, Reading, MA, 1994)

- Alternative Careers in Science: Leaving the Ivory Tower, Cynthia Robbins-Roth, ed. (Academic Press, San Diego, CA, 1998)

- Career Renewal: Tools for Scientists and Technical Professionals, Stephen Rosen and Celia Paul (Academic Press, San Diego, CA, 1997)

- Guide to Nontraditional Careers in Science, Karen Young Kreeger (Hemisphere, Bristol, PA, 1998)

- To Boldly Go: A Practical Career Guide for Scientists, Peter S. Fiske (American Geophysical Union, Washington, DC, 1996)

\section{Congressional Fellowships:}

- AAAS Public Policy Fellowships for Scientists and Engineers http://www.aaas.org/spp/dspp/stg/cover.htm

- American Chemical Society http:/ / www.acs.org/govt/pubs/5st46.htm

- American Physical Society and American Institute of Physics Congressional Science Fellowship Program

http:/ / www.aps.org/public_affairs/fellow.html

- Materials Research Society/Optical Society of America Congressional Science and Engineering Fellowship http:/ / www.mrs.org/pa/fellowship/

\section{STOP MANUALY BALAWGING!}

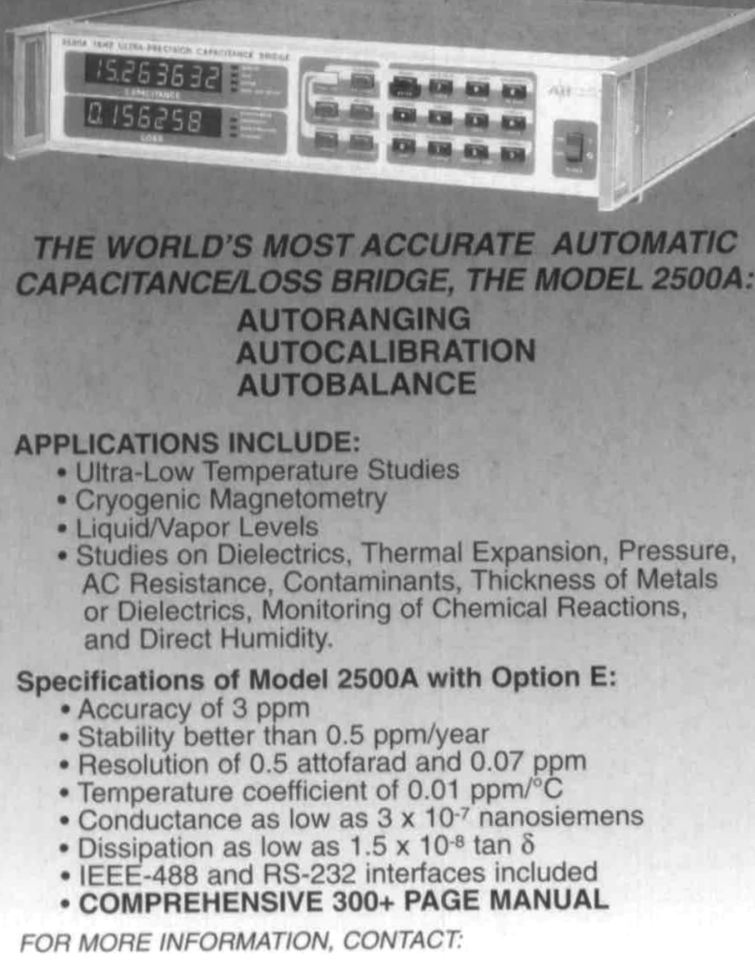

ANDEEN-HAGERLING, INC.

31200 Bainbridge Rd.

Cleveland, Ohio 44139-2231 U.S.A.

Phone: (440) 349-0370 Fax: (440) 349-0359

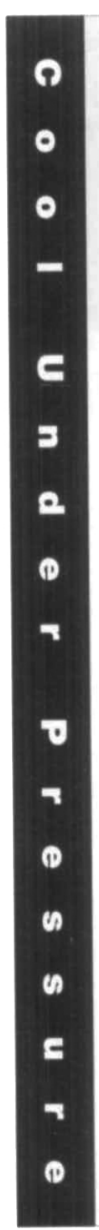

Hall Measurement System ".....................

MMR's low cost, Turnkey Hall Effect Measurement System provides user programmed computer controlled measurement and data acquisition over a temperature range of $-200^{\circ} \mathrm{C}$ to $+300^{\circ} \mathrm{C}$ - without the use of liquid nitrogen. The system measures magneto resistivity, four point resistivity. sheet resistivity, sheet number, mobility, Hall coefficient, and carrier density using the Van der Pauw and Hall measurement techniques.

Circle No. 34 on Reader Service Card.

\begin{tabular}{l}
\begin{tabular}{ll} 
Measurement Ranges (somewhat dependent on sample thickness) \\
\hline Resistivity & $10^{-4}$ Ohm- $\mathrm{cm}$ to $10^{+13} \mathrm{Ohm}-\mathrm{cm}$ \\
Carrier Mobility & $1 \mathrm{~cm}^{2} /$ volt-sec $1010^{+7} \mathrm{~cm}^{2} /$ volt-sec \\
Carrier Density & $10^{+3} \mathrm{~cm}^{-3}$ to $10^{+19} \mathrm{~cm}^{-3}$
\end{tabular} \\
\hline
\end{tabular}

For more information about the Hall Effect Measurement System, contact Bob Paugh at 415 / 962-9620 or bobp@mmr.com. Or visit our web page at http://www.mmr.com.

WMR MMR Technologies, Inc.

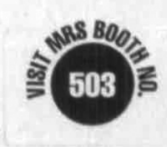

Circle No. 16 on Reader Service Card. 
a national laboratory operates.

In April 1998, I began a one-year assignment as a senior policy analyst at the White House Office of Science and Technology Policy (OSTP) Technology Division, on leave from Sandia National Laboratories. The Technology Division, under the direction of Duncan Moore, the Associate Director for Technology, helps to shape federal policies for harnessing technology to serve national goals and to foster a strong U.S. economy. In this position, I serve many functions which include providing advice in the analysis, development, and implementation of Presidential S\&T policy; assisting in identifying policy issues and problems requiring the Technology Division's attention; suggesting the outline, scope, schedule, and appropriate staffing for studies; and assisting in coordinating the work of the Technology Division with that of OSTP's other divisions. I also represent OSTP on a wide range of government and private sector forums.

Some of the issues for which I am re- sponsible include transportation research and a Partnership for a New Generation of Vehicles initiative; biotechnology; marine technology; environmental industrial initiatives; and eldercare technology to improve the lives of older Americans. I also serve as the OSTP point of contact for a few Technology Subcommittees of the National Science and Technology Council-an interagency arm of OSTP-including one that focuses on materials technologies.

Working in the Executive Office of the President environment is an intense and exhilarating experience. In this job, I work with creative thinkers within the White House Agencies and help identify critical technological initiatives of national interest that need to be considered by President Clinton and Vice President Gore.

As a chemistry major with a business option at the University of Richmond (UR), I never would have predicted that my career would follow such a path. Two of my undergraduate professors played an instrumental role in carving out my graduate career and introducing me to materials science and engineering.

My experience at a liberal arts college and as a head resident (resident hall manager and counselor) at UR gave me the confidence to pursue a new path. Being a head resident helped me to hone my leadership skills, while the liberal arts environment provided me with ways to look at issues from a broad base and with the creativity to step out of the academic box. I saw that I could use my doctorate in materials science in one of two ways: technically as a research scientist, or as a process whereby I could use my problemsolving skills to dissect, understand, and solve a problem. I have chosen to follow the latter.

Choosing this career path has been very stimulating for me and will provide me with skills that do not constrain me to one type of work. Someday I may parlay my skills into private industry to forecast future technical market sectors for hightech industry. After that, anything is possible. Who knows, maybe someday I will run for office.

\section{LIBRARY}

\section{Precipitation Hardening, $2 d$ ed. J.W. Martin \\ (Butterworth-Heinemann, Oxford, 1998) \\ xiv +219 pages, $\$ 74.95$ \\ ISBN 0-7506-3885-0}

The author, John Martin, is emeritus reader in physical metallurgy at Oxford University, and one of the leading physical metallurgists in Britain. Just 30 years ago, he published an iconoclastic small textbook with Pergamon Press-the first edition of the work under review here. The unusual feature about it was that twothirds of the book was devoted to reprints of 15 classical papers on aspects of precipitation hardening-complete or in the form of excerpts. That first edition, commended in a foreword by no less a metallurgist than Hume-Rothery himself, was to be the first of a series of undergraduate texts using this format, but so far as I know it remained the only member of its series (Hume-Rothery died about the time the first edition appeared). At the time, I reviewed the book enthusiastically since I had made some experiments in using classical texts as a feature of education in materials science and this book (as indeed Hume-Rothery pointed out in his foreword) could be used to train the critical and historical skills of students.

The first edition has long since been out of print, and therefore this new, scrupulously updated edition is to be welcomed. Although it has slightly fewer pages than its predecessor, it is actually slightly longer because the page size has been increased. The extracts from various classical papers now make up only $20 \%$ of the total length, and they now feature as appendices to the relevant chapters. One such extract (actually a full reprint) is a recent (1996) memoir by André Guinier (co-discoverer of GP zones) of how his 1937 breakthrough happened. (He never met the co-discoverer, the Scot G.D. Preston, whose own account is also reprinted here.) Classic extracts include a translation of Alfred Wilm's original paper of 1911, in which the mystified engineer reports on the spontaneous hardening of his aluminum alloy over a weekend, and a notable American paper by $Z$. Jeffries and R.S. Archer (1921) on the "slip interference theory of the hardening of metals." I was sorry to see that one of David Turnbull's deceptively simple papers on the effects of quenching on the resistivity of aluminum-copper alloys, included in the first edition, has been taken out; this is one of my favorite papers in all of physical metallurgy! However, instead we have a fine paper "on the yield stress of aged Ni-Al alloys" by R.G. Davies and N.S. Stoloff (1965). Both these authors are still happily active in research. A short extract from Egon Orowan's original (1948) theory of dislocation bowing and the bypassing of dispersed particles is also included.

The book offers a marvelously clear and economical exposition of the microstructure and mechanics (including fracture) of age-hardened alloys, and while most of the references, as might be expected from a mature topic, are fairly old, some recent ones cover such topics as small-angle $x$-ray and neutron scattering and the properties of $\mathrm{Al}$-Li alloys, both relatively new topics.

The book can be unreservedly recommended to those materials science professors who are not yet ashamed of including aspects of physical metallurgy in their teaching schedules. The only pity is that Hume-Rothery's principle of texts with selected extracts could not be extended to other topics in materials science.

Reviewer: Robert W. Cahn is a physical metallurgist turned materials scientist, currently attached in nominal retirement to Cambridge University. He has researched on intermetallics and many other metallurgical themes, has edited a number of journals and book series devoted to materials science, and has striven over the years to popularize materials science in the pages of Nature. He is a member of the Editorial Board of MRS Bulletin and a member of the publication's Book Review Board. 